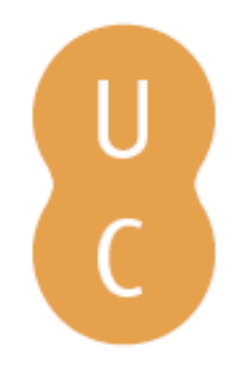

\title{
pommalina
}

\section{An experimental investigation of the effect of grass fuel load on grassfire behaviour}

Autor(es): $\quad$ Cruz, Miguel G.; Sullivan, Andrew L.; Gould, James S.; Hurley, Richard J.; Plucinski, Matt P.

Publicado por: Imprensa da Universidade de Coimbra

URL

persistente: URI:http://hdl.handle.net/10316.2/44554

DOI: $\quad$ DOI:https://doi.org/10.14195/978-989-26-16-506_37

Accessed : $\quad$ 26-Apr-2023 15:45:53

A navegação consulta e descarregamento dos títulos inseridos nas Bibliotecas Digitais UC Digitalis, UC Pombalina e UC Impactum, pressupõem a aceitação plena e sem reservas dos Termos e Condições de Uso destas Bibliotecas Digitais, disponíveis em https://digitalis.uc.pt/pt-pt/termos.

Conforme exposto nos referidos Termos e Condições de Uso, o descarregamento de títulos de acesso restrito requer uma licença válida de autorização devendo o utilizador aceder ao(s) documento(s) a partir de um endereço de IP da instituição detentora da supramencionada licença.

Ao utilizador é apenas permitido o descarregamento para uso pessoal, pelo que o emprego do(s) título(s) descarregado(s) para outro fim, designadamente comercial, carece de autorização do respetivo autor ou editor da obra.

Na medida em que todas as obras da UC Digitalis se encontram protegidas pelo Código do Direito de Autor e Direitos Conexos e demais legislação aplicável, toda a cópia, parcial ou total, deste documento, nos casos em que é legalmente admitida, deverá conter ou fazer-se acompanhar por este aviso.

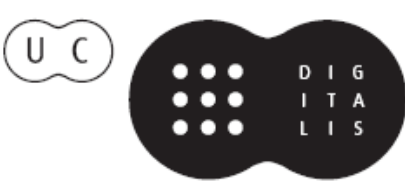




\section{ADVANCES IN}

\section{FOREST FIRE RESEARCH}

\section{8}

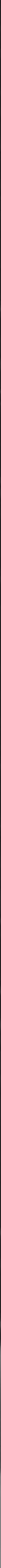




\title{
An experimental investigation of the effect of grass fuel load on grassfire behaviour
}

\author{
Miguel G. Cruz*; Andrew L. Sullivan; James S. Gould, Richard J. Hurley, Matt P. Plucinski \\ CSIRO. GPO Box 1700, Canberra, ACT 2601, Australia, \{miguel.cruz@csiro.au*\}
}

\begin{abstract}
The effect of grass fuel load on fire propagation, behaviour and fire danger has been a contentious issue for some time in Australia. Various implementations of fire behaviour and fire danger formulations have placed different emphases on the effect of fuel load on model outputs, which has created uncertainty in the operational assessment of fire potential and has led to user and public distrust in the model outputs.

A field-based experimental burning program was conducted to quantify the effect of fuel load on the rate of spread and behaviour of fire in grasslands. A total of 58 experimental fires $(33 \times 33 \mathrm{~m}$ plots) conducted at six sites across Australia were analysed. Mean fuel loads ranged between $0.17 \mathrm{~kg} / \mathrm{m}^{2}$ and $1.05 \mathrm{~kg} / \mathrm{m}^{2}$. Fire spread rate and fireline intensity ranged between 12.5 and $150 \mathrm{~m} / \mathrm{min}$ and 1260 and $18700 \mathrm{~kW} / \mathrm{m}$, respectively.

Contrary to current modelling assumptions used in Australia, we found an inverse relationship between fuel load and fire spread rate in grasslands; i.e. as fuel load increases, fire rate of spread decreases. This result is valid for grasslands where fuel load is not a limiting factor for fire propagation (e.g., load $>0.05 \mathrm{~kg} / \mathrm{m}^{2}$ ). We model the effect of fuel load on the rate of fire spread through regression analysis and an iterative backtracking method to produce a fuel load function that can be applied to current recommended operational grassfire spread models used in Australia.

We found that areas with standing continuous grass have the potential to sustain very high rates of fire spread, regardless of the fuel load. An increase in fuel load does not result in an increase in rate of fire spread, as assumed in certain modelling frameworks and some long held beliefs in Australia.
\end{abstract}

Keywords: fire behaviour modelling, fire prediction, fire danger rating

\section{Introduction}

The effect of grass fuel load on fire behaviour and grassfire danger index has been a contentious issue for many years in Australia. Early grassfire behaviour prediction tools used in Australia assumed the rate of forward spread of a fire to be directly proportional to fuel quantity (McArthur 1960). This effect was later removed (McArthur 1966) due to the (1) absence of direct evidence and; (2) the dependence of the biomass quantity in a grass sward on the structural properties of the grass species, i.e., higher fuel load grasses are typically characterized by coarser, lower surface area-to-volume ratio, fuel particles (Luke and McArthur 1978). Luke and McArthur (1978, p. 117) suggested that the effects of these two variables might cancel each other, and a direct effect of fuel load on fire spread rate might not be observable. In the early 1980s, a fuel load effect was retro-fitted to the Mk 4 Grassland Fire Danger Meter (Purton 1982) which confused the issue further. Cheney et al. (1993) undertook a large field experiment and found that fuel load did not have a significant effect on grassfire rate of spread. Despite these findings, a fuel load effect has continued to be applied in operational decision support tools in Australia (e.g. Purton 1982; Setterfield et al. 2014).

The objective of our study was to quantify the effect of grass fuel bed structure and biomass across a wide range of values on the rate of forward spread and flame characteristics of free-burning grassfires in Australia. 


\section{Methods}

Experimental fires were conducted at six locations across eastern Australia. Each site was characterised by a continuous cover of standing grass. Experimental fires were conducted in plots 33 $\times 33 \mathrm{~m}$, separated by a $3 \mathrm{~m}$ wide mown grass fuel breaks. All experimental fires used in the analysis were conducted in fully cured grasses.

Fires were ignited on the upwind edge of each plot with a line ignition. This was achieved by two people with hand-held drip-torches starting from the adjacent corners and travelling towards the centre of the plot edge. Ignition lines were offset when wind direction was not perpendicular to the plot boundary, but maintaining the ignition line length. It generally took 10-12 sec to set a continuous flame front that would ensure a well-developed headfire and pseudo-steady state propagation by the time the fire reached half of its intended run (Fig. 1).

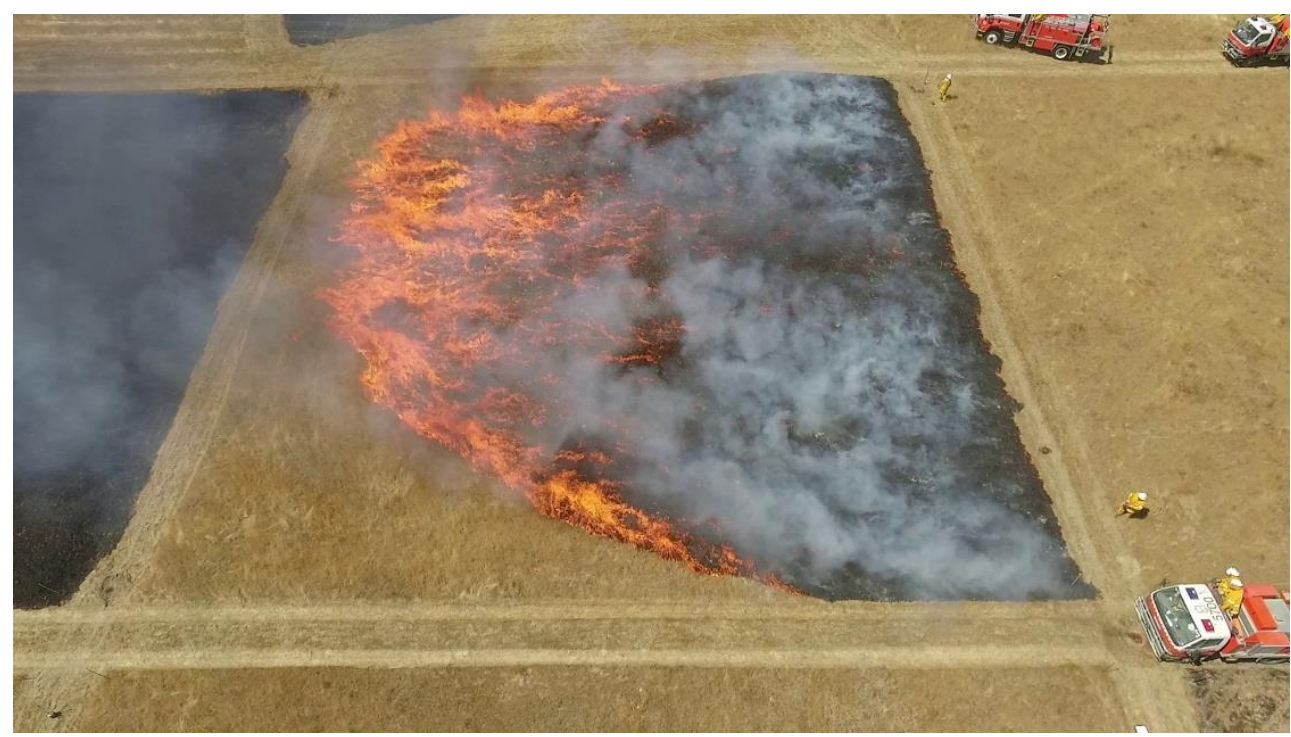

Figure 1 - Typical high intensity fire propagation from a line source ignition in a grassland fire experimental plot. Photos was taken 30 seconds after the ignition start.

Grass fuels were sampled for physical structure (load, height, compactness). An automatic weather station measuring air temperature, relative humidity and solar radiation at $1.5 \mathrm{~m}$ above ground and at 10-min intervals was established at each experimental site. At this location wind speed and direction at 2 and 10-m height were measured with 2-D sonic anemometers sampled and logged at a frequency of $10 \mathrm{~Hz}$. For each individual burn, one 2-D sonic anemometer at 2- $\mathrm{m}$ height was located approximately $35 \mathrm{~m}$ up-wind of the ignition line, with wind speed and direction sampled and logged at $10 \mathrm{~Hz}$. Prior to each experimental fire, three fuel moisture content samples (20-30 g) were collected and sealed in airtight metal tins. The behaviour of each experimental fire was monitored using in-situ instrumentation, ground-based and aerial videography and visual observations by experienced fire behaviour observers. The observers in close proximity to the fire monitored various flame front characteristics (i.e. depth, height and angle), fuel responsible for propagation and the duration of indraught winds (i.e. lulls in fire propagation) throughout the duration of each experimental fire.

Rate of fire spread (R, $\mathrm{m} / \mathrm{min}$ ) was determined from measurements of the time of fire arrival at grid points (grid spacing $7.5 \times 7.5 \mathrm{~m}$ or $10 \times 10 \mathrm{~m}$ ) within each experimental plot and video imagery. Time of fire arrival was assumed to coincide with a temperature of $320^{\circ} \mathrm{C}$ measured by $1.5-\mathrm{mm}$ diameter, type $\mathrm{K}$ metal-sheathed thermocouples connected to small dataloggers logging at $1 \mathrm{~Hz}$. Video imagery 
captured from remotely piloted aircraft (i.e. drones) or from the top of 5- or 10-m poles were used to determine flame movement from which rate of spread could be visually estimated.

Statistical analysis used the R 2.13.1 software package (R Development Core Team 2012). The effect of fuel load and other fuel characteristics in rate of fire spread was explored using two distinct approaches. The first approach was based on linear and nonlinear regression analysis. Because the fuel variable effect on grassland rate of fire spread determined through this approach cannot be readily incorporated into existing fire spread models used in Australia a second approach was used to develop a multiplicative function that (1) described the effect of fuel load or bulk density on rate of fire spread; and (2) could be implemented into the current operational model for undisturbed grasslands (Cheney et al. 1998). In this approach the Cheney et al. (1998) model was used to predict the experimentally observed rate of fire spread, and a fuel effect function added to the model to explain the effect of fuel load or bulk density. From the possible functional forms, an iterative process was used to find the formulation that result on the minimisation of both the root mean square error and bias while still producing adequate results outside the bounds of the experimental data.

\section{Results}

A total of 58 experimental fires were available for the analysis. Total fuel load at the plot level ranged from a minimum of $0.17 \mathrm{~kg} / \mathrm{m}^{2}$ to $1.05 \mathrm{~kg} / \mathrm{m}^{2}$. Observed rate of fire spread varied between 12.5 and $150 \mathrm{~m} / \mathrm{min}$. The dataset had 16 fires ( $25 \%$ of the data) with a fireline intensity above 10000 $\mathrm{kW} / \mathrm{m}$.

Rate of fire spread was significantly correlated with wind speed $(\mathrm{p}<0.001$; Table 3$)$ and had a significant inverse relationship with fuel load $(\mathrm{r}=-0.50 ; \mathrm{p}<0.001)$. It was poorly correlated with bulk density $(r=-0.19 ; \mathrm{p}>0.05)$ and sampled dead fuel moisture $(r=0.12 ; \mathrm{p}=0.37)$.

Multiple linear regression analysis was used to develop a model using 2-m wind speed, dead fuel moisture content and a fuel structure metric, fuel load, fuel bed bulk density or fuelbed height. For this modelling approach wind speed was highly significant ( $\mathrm{p}<0.001)$. Sampled dead fuel moisture was not a significant predictor $(\mathrm{p}=0.76)$, but the estimated dead fuel moisture was marginally significant $(p=0.09)$. Fuel load was a significant predictor of rate of fire spread $(p=0.02)$ through an inverse relationship (i.e. an increase in fuel load results in a reduction in rate of fire spread). This model explained $71 \%$ of the variation in the dataset. Fuel bulk density was also a significant predictor of rate of spread $(\mathrm{p}=0.02)$. A similar model with fuel bed height found this variable not to be significant ( $p$ $=0.41$ ).

Non-linear regression analysis identified both fuel load $\left(w, \mathrm{~kg} / \mathrm{m}^{2}\right)$ and fuel bed bulk density $\left(\rho_{b}\right.$, $\left.\mathrm{kg} / \mathrm{m}^{3}\right)$ in isolation as significant $(\mathrm{p}<0.05)$ predictors of rate of fire spread. The best model form that had these variables incorporated through a power function:

$$
\begin{aligned}
& R=5.03 U_{2}^{0.89} \exp \left(-0.016 M_{e}\right) w^{-0.23} \\
& R=3.62 U_{2}^{1.05} \exp \left(-0.005 M_{e}\right) \rho_{b}{ }^{-0.32}
\end{aligned}
$$

Where $U_{2}$ is wind speed $(\mathrm{km} / \mathrm{h})$ measured at 2-m height and $M_{e}$ is the dead fuel moisture content (\%) estimated using Cheney et al. (1998) model parameterization of McArthur (1960) fuel moisture tables. The analysis showed both fuel parameters to have a negative effect on the rate of fire spread. Both models had a wind exponent close to 1 . The estimated dead fuel moisture was not significant in either model, although a stronger effect was found for the fuel load model (Eq. 1). The model with 
bulk density (Eq. 2) had a comparable fit as indicated by the residual standard error (14.99 and 15.27, respectively) and the mean absolute error (11.8 and $11.7 \mathrm{~m} / \mathrm{min})$.

Given the comparable effect of fuel load and fuel bed bulk density on rate of fire spread, we decided to use fuel load, a variable of simpler estimation, to develop a fuel structure effect function for operational applications. For this modelling approach we first applied the Cheney et al. (1998) undisturbed grassland model to the experimental dataset. For this simulation $U_{2}$ was converted to $U_{10}$ using a wind reduction factor of 0.81 , as determined from vertical wind profiles (Cruz et al. 2017). The fuel moisture content used in the simulations is the one estimated by Cheney et al. (1989) used in Cheney et al. (1998) model parameterization. The model predicted the observed rate of fire spread with a mean absolute error of $19.3 \mathrm{~m} / \mathrm{min}$, and a mean bias error of $1.28 \mathrm{~m} / \mathrm{min}$. Residual analysis revealed a relatively high over-prediction bias for fuel loads greater than $0.6 \mathrm{~kg} / \mathrm{m}^{2}$ and an under prediction bias for fires burning with estimated fuel moisture contents greater than $10 \%$.

To develop a fuel load function we tested several functional forms available. From the ones tested we choose to model the fuel load effect with a Ricker function due to its form, with an initial growth up to a local maximum followed by a gradual decrease:

$$
\Phi(\mathrm{w})=\mathrm{r}_{1}+\mathrm{r}_{2} w \exp \left(-\mathrm{r}_{3} w\right)
$$

where $\Phi(w)$ is the fuel load effect function, and $r_{2}$ and $r_{3}$ are the two parameters in the Ricker function. To find the best estimates for $r_{1}, r_{2}$ and $r_{3}$ we apply the fuel load function to the Cheney et al. (1998) model as a multiplicative factor.

The model was then run iteratively with coefficients $r_{2}$ and $r_{3}$ varying systematically between 1 and 5 (increments of 0.1 ) and 2 and 4 (increments of 0.1), respectively. The best results (lower RMSE and lowest bias error) were found for an $r_{1}$ of $0.7, r_{2}$ of 2.4 and $r_{3}$ of 3.4 (Fig. 2). These coefficients resulted in a root mean square error of 1.31 ; a mean absolute error of $17.7 \mathrm{~m} / \mathrm{min}$ and mean bias error of -1.4 $\mathrm{m} / \mathrm{min}$.

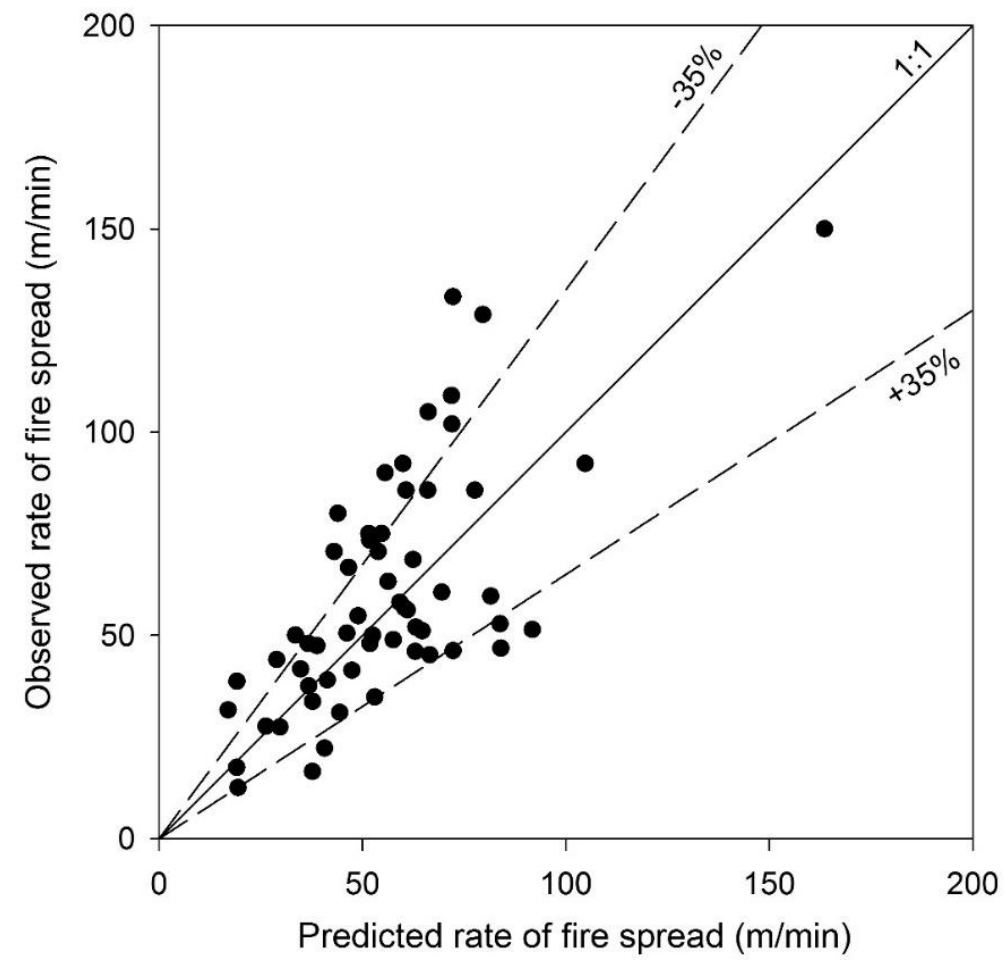

Figure 2 - Observed vs predicted rate of fire spread by Cheney et al. (1998) undisturbed model with the fuel load effect function (Eq. 3). 
Figure 3 presents the relative effect of the fuel load function over the range 0.1 to $1.5 \mathrm{~kg} / \mathrm{m}^{2}$. The relative effect has a low value of 0.92 for a fuel load of $0.1 \mathrm{~kg} / \mathrm{m}^{2}$ and peaks to 1.0 for fuel loads between 0.25 and $0.4 \mathrm{~kg} / \mathrm{m} 2$. At extremes of the fuel load range, the relative effect is 0.76 for a low fuel load value of $0.01 \mathrm{~kg} / \mathrm{m}^{2}$ and asymptotes for fuel load values above $1.4 \mathrm{~kg} / \mathrm{m}^{2}$, with a relative of effect of 0.74 for an extreme grass fuel load value of $2.0 \mathrm{~kg} / \mathrm{m}^{2}$. Figure 3 also shows the advantages of the Ricker function over the nonlinear power function used in Eq. 1. Although the fit statistics were similar for the datasets, the regression models provide unsatisfactory results for the lower ( $\mathrm{w}<0.3$ $\mathrm{kg} / \mathrm{m}^{2}$ ) range of fuel load. Similar situation, but not as dramatic occurs for the upper range of fuel load (e.g. $\left.\mathrm{w}>1.2 \mathrm{~kg} / \mathrm{m}^{2}\right)$.

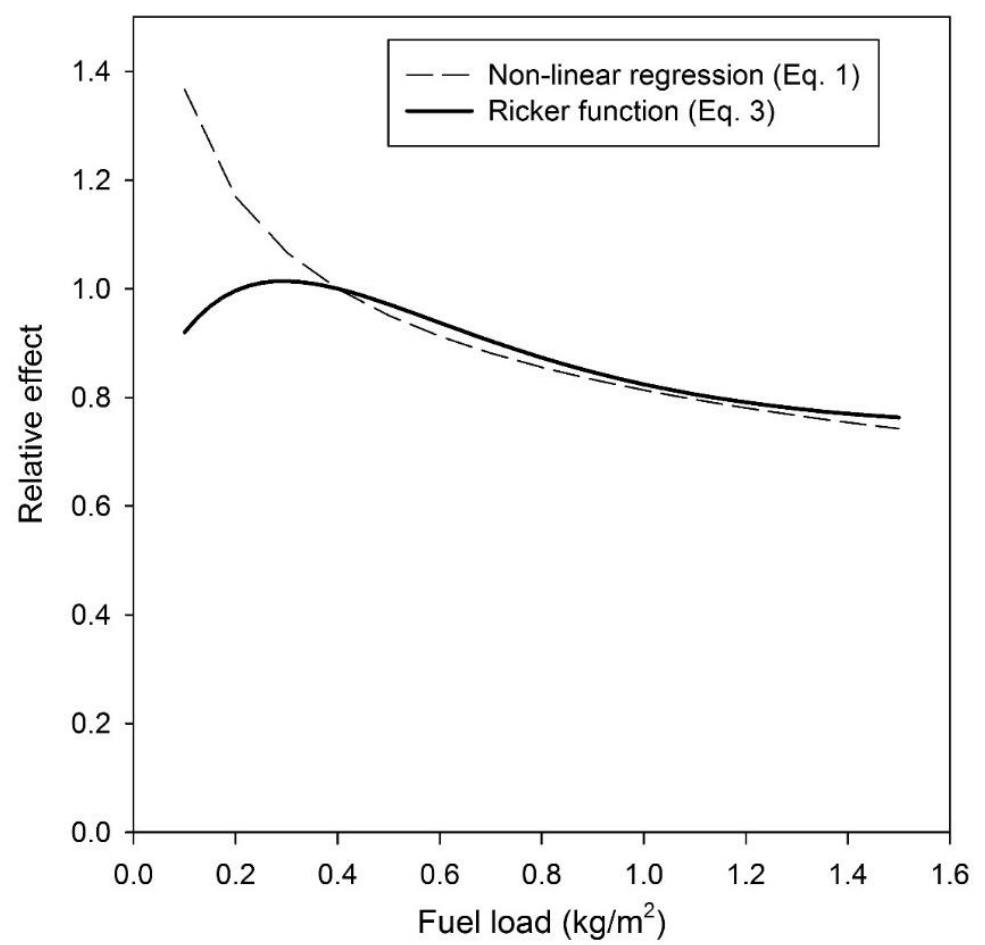

Figure 3 - Relative effect of the tested fuel load functions on the rate of spread of grassfires

\section{Discussion and conclusions}

Our analysis showed that there is a statistically significant, inverse relationship between grass fuel load and rate of fire spread, i.e., an increase in fuel load leads to a decrease in rate of fire spread. Although it might seem surprising, our results follow the trend from Cheney et al. (1993) study. In that study, conducted over a narrower range of fuel loads than in our study $\left(0.17-1.05 \mathrm{~kg} / \mathrm{m}^{2} \mathrm{cf} .0 .23\right.$ $0.57 \mathrm{~kg} / \mathrm{m}^{2}$ for Cheney et al. (1993)) the authors found a non-significant influence of fuel load on rate of fire spread, which had the same trend as that found in our study. The results from Cheney et al. (1993) and ours suggest that the effect is not linear, with minimal effect within the 0.2 to $0.4 \mathrm{~kg} / \mathrm{m}^{2}$ range, and a stronger effect for fuel loads between 0.5 and $1.1 \mathrm{~kg} / \mathrm{m}^{2}$. In the absence of data beyond this range, the fuel load effect function given here asymptotes to a value of approximately $74 \%$ of the maximum rate of spread at a fuel load of $2.0 \mathrm{~kg} / \mathrm{m}^{2}$. Beyond this value the model yields negligible changes for increasing fuel loads. These results are applicable to environments where fuel load is not a limiting factor. In sparse cover grasslands found in arid and semi-arid regions of Australia, fuel load, as a surrogate of cover, is a limiting factor where decreases in fuel load might constrain the forward propagating flux to unburned fuels and limiting flank propagation. 
Our results are contrary to the current Australian practice of assuming a direct positive effect of fuel load on rate of fire spread (Tolhurst et al. 2008) and fire danger rating (Purton 1982). Methods relying on this effect should be revised in light of this and previous (Cheney et al. 1993) scientific evidence.

\section{Acknowledgements}

The authors are grateful to the Queensland Fire and Emergency Services (QFES), and in particular Andrew Sturgess, for supporting this research project. The authors also thank the Country Fire Authority (CFA) of Victoria, in particular David Nichols and Alen Slijepcevic, and the NSW Rural Fire Service (RFS), in particular Simon Heemstra and Laurence McCoy, for their contributions to this research. We also acknowledge the important collaborations of Susan Kidnie, Rachel Bessell, Musa Kilinc, Nigel Buchanan and Tim Wells from CFA, Victoria. At each experimental burning site, suppression support was provided by local brigades who were mainly volunteers and are too numerous to mention individually. Their critical support for the safe and effective conduct of the experimental fires is greatly appreciated.

\section{References}

Cheney NP, Gould JS, Catchpole WR (1993) The influence of fuel, weather and fire shape variables on fire-spread in grasslands. International Journal of Wildland Fire 3, 31-44.

Cheney NP, Gould JS, Catchpole WR (1998) Prediction of fire spread in grasslands. International Journal of Wildland Fire 8, 1-13.

Cheney NP, Gould JS, Hutchings PT (1989) Prediction of fire spread in grassland. CSIRO, Canberra, ACT.

Cruz MG, Sullivan AL, Hurley RJ, Plucinski MP, Gould JS (2017) The effect of fuel load and structure on grassland fire behaviour and fire danger. CSIRO.

Luke RH, McArthur AG (1978) 'Bushfires in Australia.' (Australian Government Publishing Service: Canberra)

McArthur AG (1960) Fire danger rating tables for annual grasslands. Forestry and Timber Bureau, Australia Mimeograph Report, Canberra.

McArthur AG (1966) Weather and grassland fire behaviour. Commonwealth of Australia, Forestry and Timber Bureau Leaflet 100, Canberra, ACT.

Purton C (1982) 'Equations for the McArthur Mark 4 grassland fire danger meter.' (Bureau of Meteorology: Melbourne, VIC)

R Development Core Team (2012) 'R: A Language and environment for statistical computing.' (R Foundation for Statistical Computing: Vienna, Austria).

Setterfield SA, Rossiter-Rachor N, Douglas MM, McMaster D, Adams V, Ferdinands K (2014) 'The impacts of Andropogon gayanus (gamba grass) invasion on the fire danger index and fire management at a landscape scale, 19th Australasian Weeds Conference, Hobart, Tasmania'.(Ed. M. Baker.).

Tolhurst K, Shields B, Chong D (2008) Phoenix: development and application of a bushfire risk management tool. The Australian Journal of Emergency Management 23, 47-54. 